\title{
Exports of Ukraine as a global challenge for its future
}

\author{
Sergii Sardak ${ }^{1}$, Svitlana Radziyevska ${ }^{2,}$, and Ivan $\mathrm{Us}^{3}$ \\ ${ }^{1}$ Oles Honchar Dnipro National University, Department of Economics, Entrepreneurship, and Management of Enterprises, 72, Gagarin \\ Ave, Dnipro, 49010, Ukraine \\ ${ }^{2}$ The State University of Infrastructure and Technology, Department for Theoretical and Applied Economics, 9, Kyrylivska St., Kyiv, \\ 04080, Ukraine \\ ${ }^{3}$ The National Institute for Strategic Studies, Department of Foreign Economic Policy, 7-a, Pyrogova St., Kyiv, 01030, Ukraine
}

\begin{abstract}
Exports are critical for the highly open Ukrainian economy which is characterized by the large trade deficit. Since independence the major consumers of the Ukrainian products have been the CIS and the EU. Conflict with Russia led to the significant decline of the volume of Ukraine's export commodities. The export analysis, based on the data provided by the State Statistics Service of Ukraine for the period of 20102018 allowed to identify the problems and to come up with possible solutions focusing primarily on the role of the Government of Ukraine in strengthening cooperation with the EU. Firstly, it is suggested to take the institutional steps aimed at expanding and deepening the integration towards the common economic space with the EU, especially the common customs space. Secondly, to explore the opportunities of exporting goods to the countries, with which the EU has signed regional trade agreements. The third step is related to the changing role of Ukraine in the global model of the transformation of the world economy and requires the combination of close cooperation with the EU, on the one hand, and the powerful economies, on the other, thereby contributing to the formation of non-confrontational relations between East and West.
\end{abstract}

\section{Introduction}

The high-level openness of the economy makes Ukraine very vulnerable to the impact of strengthening global economic and integration processes $[1,2,3]$.

Since independence Ukraine had been balancing in terms of its integration aspirations between Russia and the European Union (EU) up until 2014 [4]. The global crisis of 2008-2009 challenged the trade, but the geopolitical conflict of 2014 brought about much more difficult time for the whole country, resulting in the transformations of the major trade flows of Ukraine [5].

Russia's trade wars, an embargo on agricultural products, the termination of free trade agreement (FTA) in January 2016 hit the Ukrainian economy hard, led to the sharp decrease in bilateral trade and the significant decline of the volume of deliveries of Ukraine's main export commodities, among them the goods with highadded value. The conflict with Russia also hindered the country's transport and transit potentials, preventing trade with neighboring states.

So, the future of Ukraine has become dependent on its trade relations with the EU and the countries which could compensate for Ukraine's loss of the Russian market. The severe economic situation is pushing Ukraine towards surviving by promoting goods not only on the markets of Central and Eastern Europe, but also on those of Asia and Africa. The priority issue for Ukraine today is to re-orient its exports and avoid the trap of being a raw materials export economy [6].

The objective of the paper is to suggest the ways to promote exports of goods of Ukraine by improving trade relations with the EU, the Commonwealth of Independent States (CIS) and the other old partners, as well as by capturing new markets in Asia and Africa, and building relations with the leading countries on the East as a means of strengthening the economy of Ukraine in order to find its place in the global model of the transformation of the world economy. This task is significant, as increased exports of goods will generate many benefits to the Ukrainian economy which has been in the devastating economic situation since the global crisis.

\section{Ukraine's free trade agreements and multi-vector trade policy}

In the 1990s young independent Ukrainian state practiced multi-vector international economic policy. On the one hand, Ukraine maintained the old trade relations with the former USSR republics and participated in the integration processes in the framework of the CIS, Single Economic Space, The Eurasian Economic Union (EAEU) and, on the other hand, Ukraine declared its interest in joining the EU and started building new trade relations with prospective countries all over the world. In the literature of the field, it is emphasized that regional integration is essential to maximizing the benefits of globalization for the Least Developed Countries (LDCs) since it has the potential to attract investment flows, expand market size, develop regional infrastructure and connectivity [7].

\footnotetext{
*Corresponding author: svitrad98@ukr.net
} 
Let's review Ukraine's milestones in terms of FTAs, entered into force. Focusing on Ukraine's trade with the eastern partners, it's necessary to state that right after obtaining independence in 1991 Ukraine signed the Agreement establishing the CIS along with Russia and Belarus. The heads of eleven former Soviet Republics (except Georgia and the Baltic states) signed the amendment to the Agreement founding the CIS on December 21, 1991. On October 18, 2011 the FTA was signed by eight countries: Armenia, Belarus, Kyrgyzstan, Kazakhstan, Moldova, Tajikistan, Russia and Ukraine, it entered into force on September 20, 2012. Azerbaijan and Turkmenistan did not sign the Agreement, while Uzbekistan joined it later, in 2012.

According to the Regional Trade Agreements (RTAs) database of the World Trade Organization, Ukraine has signed the following FTAs with the CIS countries: Turkmenistan (entered into force on November 4, 1995), Uzbekistan (January 1, 1996), Georgia (June 4, 1996), Azerbaijan (September 2, 1996), Armenia (December 18, 1996), Kyrgyzstan (March 20, 1998), Kazakhstan (October 19, 1998), Tajikistan (July 11, 2002), Moldova (May 19, 2005), Belarus (November 11, 2006) [8]. Also Ukraine has signed FTA with the countries of the Single Economic Space (Belarus, Kazakhstan, Russian Federation) which entered into force on May 20, 2004, and with the Organization for Democracy and Economic Development (Georgia, Ukraine, Azerbaijan, Moldova - GUAM) which entered into force on December 10, 2003.

Considering Ukraine's efforts towards strengthening relations in the western direction, it's worth mentioning that the first EU-Ukraine top-level meeting was held on September 14, 1992 and was followed by the Agreement between the European Communities and Ukraine on trade in textile products, signed on May 5, 1993 and the Agreement on Partnership and Cooperation between Ukraine and the EU, signed on June 14, 1994. The year 1998 should be highlighted since the President of Ukraine Leonid Kuchma in June signed the Decree 615 approving the Strategy of Ukraine's integration to the EU. On February 18, 2008 the FTA negotiations were launched [9]. Ukraine signed FTA with Macedonia (entered into force on July 5, 2001), the European Free Trade Association (EFTA), consisting of Switzerland, Norway, Liechtenstein, Iceland (entered into force on June 1, 2012), Montenegro (January 1, 2013), Canada (August 1, 2017). Finally, the FTA with Israel was signed in January 2019.

However, in 2013 the president of Ukraine Victor Yanukovych did not sign the Association Agreement, planned for November 2013, which led to the Revolution, the overthrow of the government and Russia's aggression against Ukraine. Hence, in 2014 the Association Agreement was signed, including its Deep and Comprehensive Free Trade Area (DCFTA) part. The DCFTA entered into force on April 23, 2014.

It should be noted that Ukraine indeed had been invited to join the EAEU for a few years. The EAEU was eventually established in January 2015, the member states are the Republic of Armenia, the Republic of Belarus, the Republic of Kazakhstan, the Kyrgyz
Republic and the Russian Federation. In January 2010, the Customs Union of Belarus, Kazakhstan and Russia was launched: the Common Customs Tariff was implemented, customs formalities and customs control at the internal borders were cancelled, and free movement of goods within the three states was ensured [10]. If Ukraine were to join the Customs Union, it would have no choice but to terminate all its existing FTAs with other countries, including the one with the EU under the Agreement. If, on the other hand, Ukraine wanted to maintain independent preferential trade relations with both the EU and the Customs Union, this would still be possible, through the establishment of Free Trade Areas. The Agreement was meant to do just that: to leave Ukraine free to determine its own trade policy [11].

To sum up, Ukraine has concluded 19 FTAs (EU, CIS, EFTA, GUAM, Canada, Georgia, Montenegro, Macedonia, Israel) covering 46 countries with over 810 million potential consumers of the Ukrainian products. The talks have begun on signing FTAs with Turkey and Serbia.

\section{Ukraine's exports of goods as the key to economic growth}

Exports are of highest priority for open Ukrainian economy and remain the driving force of economic growth of the country. According to the World Bank, in 2017 exports of goods and services are $47.95 \%$ of GDP [12].One of the key peculiarities of the economy is that the share of trade in goods in all trade in goods and services makes up for more than $80 \%$, e.g. $81.5 \%$ in 2015 ; $80.6 \%$ in 2016 ; $82.3 \%$ in 2017 .

A closer look at Ukraine's export performance during the period between 2010 and 2018 shows that there are three problems which need to be solved.

The first problem for Ukraine in foreign trade relations is the large trade deficit, which in goods reached 9.801 billion dollars in 2018, the result of great surplus of high value-added imports of goods over exports comprised by agriculture, metals and other low value goods. The balance of trade in goods has been negative since 2005, except for 2015 when it was positive of 610.7 million dollars [13].

The second problem is the significant decline in the volume of export commodities. The tendency towards the reduction of Ukraine's exports in products remains on the agenda since the post-crisis period (with total exports of 50744.3 million dollars for 2010 and 47339.9 million dollars for 2018).

The linear regression trend model of the relationship between the two variables - the time and the size of goods produced for exports is calculated by the method of least squares. The results presented in the tables are based on the Microsoft Excel program. The pair linear regression is applied in the research.

The models enable, firstly, the economic interpretation in terms of positive or negative dynamics of the goods exported over the analyzed period of time and, secondly, the analysis of the current economic situation, as well as the suggestions on the ways for its 
improvement. Table 1 indicates that the trend of the volume of exports of goods for the period of 2010-2018 is $y=-2893 x+66404$. To confront the problem, the Cabinet of Ministers of Ukraine adopted the Program on active promotion of export of goods and the strengthening of the domestic market. The Program was approved by the Cabinet of Ministers of Ukraine on December 11, 2014 and aimed at doubling the total exports by 2019, it also presupposed conclusion of FTAs with Canada, Turkey, Israel, and two regional integration organizations - The Cooperation Council for the Arab States of the Gulf (originally known as the Gulf Cooperation Council - GCC), the Economic Community of West African States - ECOWAS) [14]. As of today, referring to the program, Ukraine has concluded FTAs with Canada and Israel, but failed to increase exports and to conclude the other planned FTAs.

Table 1. Ukraine's exports of goods in million dollars, 20102018.

\begin{tabular}{|c|c|c|c|c|}
\hline & $\mathbf{2 0 1 0}$ & $\mathbf{2 0 1 1}$ & $\mathbf{2 0 1 2}$ & $\mathbf{2 0 1 3}$ \\
\hline Total & 50744.3 & 67594.1 & 67779.8 & 62305.9 \\
\hline EU & 12916.4 & 17862.9 & 16937.9 & 16573.5 \\
\hline CIS & 18482.9 & 25835.8 & 24911.3 & 21672.1 \\
\hline
\end{tabular}

\begin{tabular}{|c|c|c|c|c|}
\hline & $\mathbf{2 0 1 4}$ & $\mathbf{2 0 1 5}$ & $\mathbf{2 0 1 6}$ & $\mathbf{2 0 1 7}$ \\
\hline Total & 53901.7 & 38127.1 & 36361.7 & 43264.7 \\
\hline EU & 17002.9 & 13015.2 & 13496.3 & 17533.4 \\
\hline CIS & 14882.3 & 7806.1 & 6031.5 & 6916.4 \\
\hline
\end{tabular}

\begin{tabular}{|c|c|c|}
\hline & $\mathbf{2 0 1 8}$ & Trends 2010-2018 \\
\hline Total & 47339.9 & $\boldsymbol{y}=\mathbf{- 2 8 9 3} \boldsymbol{x}+\mathbf{6 6 4 0 4}$ \\
\hline EU & 20158.5 & $\boldsymbol{y}=\mathbf{2 9 2 . 3} \boldsymbol{x}+\mathbf{1 4 7 0 5}$ \\
\hline CIS & 7027.0 & $\boldsymbol{y}=-\mathbf{2 5 7 0} \boldsymbol{x}+\mathbf{2 7 6 9 1}$ \\
\hline
\end{tabular}

Source: authors' calculations, based on the State Statistics Service of Ukraine database. http://www.ukrstat.gov.ua (2018) Accessed 19 Mar 2019.

Moreover, in the 2017 President's Annual Address to the Parliament of Ukraine it was stated that Ukraine should strengthen its trade relations and cooperation with the regional organizations, especially those located in Asia, among them Association of Southeast Asian Nations (ASEAN) and the Shanghai Cooperation Organization (SCO) since they play important roles in politics, security, finance, and economy on the global level [15]. The Deputy Minister of Agrarian Policy and Food of Ukraine for European Integration Vladyslava Rutytska confirmed Ukraine's interests in signing FTA with ASEAN. Interestingly, after the global crisis the U.S. managed to double exports in 2010 reaching the goal, declared in the National Export Initiative (NEI). It is important to stress that the Government played the key role: the Export Promotion Cabinet was created, twenty agencies were working under the Trade Promotion Coordinating Committee; the National Export Strategy links the NEI and the export promotion strategy of the U.S. Government [16]. The American experience shows that exports contribute to the growth of GDP, support millions of high-paying jobs in the U.S.; have been responsible for major contributions to the economic performance of many states and metropolitan areas [17].

The analysis of the Ukrainian exports demonstrates that in 2017 Ukraine exported goods to over 200 countries. The main consumers are the EU and the CIS. As shown in table 1, there is a tendency of a great decrease in volumes of the total Ukrainian commodity exports, and especially exports of goods to the CIS while the key export market for goods has become the EU.

The third problem is low-tech exports. Ukraine is the world's fifth largest exporter of cereals and a major exporter of iron and steel. In 2017, the main exported products were sunflower seeds, maize, wheat and meslin, iron products, soya beans and colza seeds. The main imported products were fuels, vehicles, medicines, pesticides and fertilizers, machinery [3]. The researchers emphasize that as many as 38 developing countries are estimated to be dependent on a single commodity for more than $50 \%$ of their export income, while 48 countries, many of which are LDCs, depend on only two. Over the past 40 years, real prices for many of the agricultural commodities on which LDCs depend have fluctuated widely and fallen significantly overall [7]. Ukraine finds itself in the similar situation since nearly $60 \%$ of the exports of goods are raw materials: over $40 \%$ are agricultural products and more than $20 \%$ - steel. Consequently, we should agree with the scholars who argue that foreign trade of Ukraine has no effect on the improvement of innovation of the country [18], and it sounds logical that the positive impact of the export shock on innovation is magnified for high productivity firms, whereas it may negatively affect innovation in low productivity firms [19]. To tackle the third problem on December 27, 2017 the Government approved the Export Strategy of Ukraine: Roadmap for Strategic Development of Trade for the period of 2017-2021, which was developed by the Ministry of Economic Development and Trade with the assistance of the business and experts based on the methodology of the International Trade Center. The Strategy states that with an overall vision of moving Ukraine into "Knowledgeand innovation-based exports for sustainable development and success in global markets" [20].

In this respect another big challenge is that foreign markets are quite segmented for Ukrainian exports as machine-building products are orientated mainly towards post-Soviet markets, and the Russian Federation in particular, while exports to European markets constituted mostly of low value-added goods [20]. The current state of exports of Ukraine is characterized by significant changes in the dynamics of its volumes, commodity structure, geography of consumers. An analytical paper released by the National Bank of Ukraine suggests that the regional and commodity structure of Ukraine's external trade has undergone drastic changes over the last decade in response to global commodity market and geopolitical developments [21]. Thus, the overview of foreign trade performance of Ukraine for 2010-2018, based on the analysis of the data of the State Statistics Service of Ukraine, proves that it is important to focus on increasing not only the volume of exports of goods, but also the share of high-tech products in them in order to have a positive trade balance.

The Government of Ukraine, through the Ministries, and business elite of the country should work on signing RTAs with eastern partners and take the responsibility 
for solving the above mentioned three problems. In our opinion, the best way for promoting exports is the combination of Ukraine's close cooperation with the EU, on the one hand, and the powerful economies of the world, on the other, which will not only contribute to the formation of non-confrontational relations between East and West, but also will strengthen foreign trade of Ukraine and its integration into the global space.

\section{Ukraine and the EU}

Over the past five years, the importance of the EU market for Ukraine has significantly increased.

\subsection{Trade between Ukraine and the EU in 2018}

According to the results of 2018, its share in the geographical structure of both exports and imports of goods amounted to $43 \%$. Since April 2014, that is, since the introduction of temporary trade preferences for Ukraine, the EU has canceled most of the duties on Ukrainian goods. An exception has been made to the number of individual items such as wheat, maize, poultry, and others, mainly agricultural products for which there is a quotas mechanism, as well as several groups of products in the processing industry, such as vehicles (primarily cars), receiving equipment for radio broadcasting, certain types of weapons and other goods for which transitional periods (preferably 7 years) have been established until the cancellation of duties. This contributed to a gradual increase in exports of goods from Ukraine to the EU by 3,6\% in 2016 and by $29,9 \%-$ in 2017.

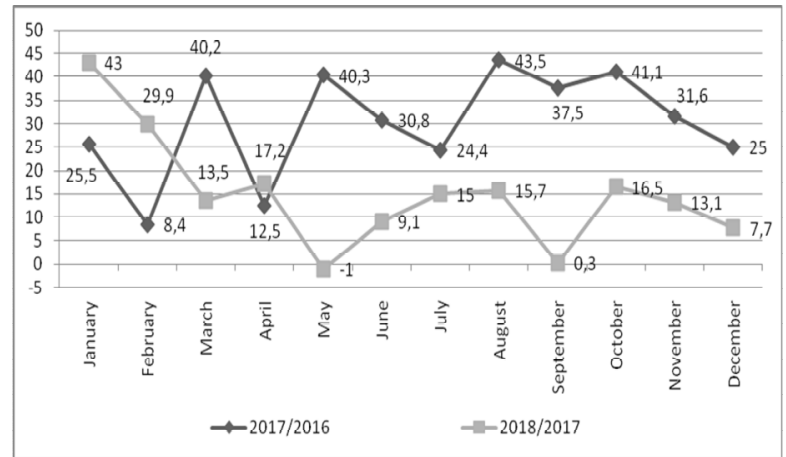

Fig. 1 Monthly dynamics of exports of goods from Ukraine to the EU in 2017 and 2018 (in \% to the corresponding month of the previous year. Source: authors'calculations, based on the State Fiscal Service of Ukraine database.

http://sfs.gov.ua/ms/f1 (2018) Accessed 10 Mar 2019.

The trend of export supply expansion continued in 2018 (exports increased by 15\%). In the middle of 2018 export growth rate slowed considerably (in May 2018 compared to May 2017 exports of goods even declined by $1 \%$ ), while the average growth rate of exports in the monthly dynamics is significantly lower than in 2017 (Figure 1).

The sectoral analysis of the goods export dynamics to the EU shows that the lower growth of export volumes in comparison with the previous year can be explained by the relatively modest growth rates of export of agricultural products (by $9 \%$, while by the end of 2017 this indicator was $40,1 \%$ ), the share of which in the commodity structure of exports to the EU is almost $26 \%$ (Figure 2). A similar situation was observed in some other sectors. Thus, exports of food products grew by $5,7 \%$, while last year growth was $22,9 \%$. Exports of machine-building industry goods increased by $14,7 \%$ versus $25,3 \%$ in 2017, while the export of transport equipment increased by almost 1\%, although in 2017 it grew by $30,2 \%$.

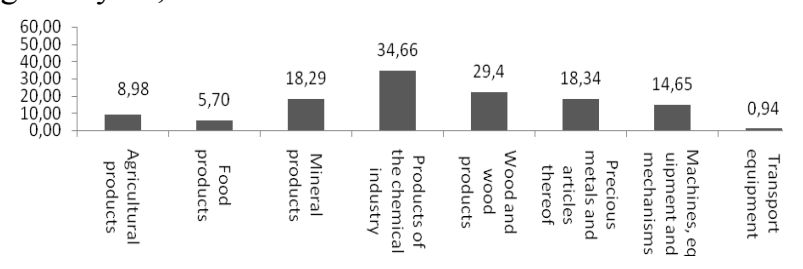

Fig. 2. Dynamics of export of commodity groups from Ukraine to the EU in 2018 compared to 2017. Source: authors' calculations, based on the State Statistics Service of Ukraine database. http://www.ukrstat.gov.ua (2018) Accessed 19 Mar 2019.

The given statistics allows us to conclude that Ukraine has almost fully used the possibilities, it has been provided with, regarding abolishment and reduction of customs duties, and now in order to further increase exports, it is necessary to take additional measures, both in terms of expanding already existing opportunities and implementing new initiatives.

\subsection{Improvement of Customs Procedures}

First of all, it is important to reduce the time and money costs when crossing the customs border with the EU and changing the volume and approaches to administering the tariff quotas provided by the EU.

Measures to reduce the costs of domestic exporters while delivering goods to the EU may become an important step for Ukraine to expand exports to the EU. Special attention should be paid to minimizing costs when crossing the EU customs border which requires harmonization of control measures carried out by the customs authorities of Ukraine and the EU, aimed at elaboration of the common approach to the customs control, the results of which will be recognized on both sides of the border.

As we can see, the steps require additional efforts from Ukraine with the focus on the following issues:

1) Harmonization of customs legislation which is a prerequisite for the implementation of all the measures aimed at simplifying the crossing of the EU customs border. To achieve this, Ukraine should finish with:

$>$ Implementation of the EU Customs Code (UCC) and other EU acquis in the customs field;

Harmonization of the Ukrainian Customs Tariff structure and the product nomenclature with those of the EU; 
Unification of the practice of applying customs legislation by the customs authorities of Ukraine and the EU.

2) Mutual Recognition of Authorized Economic Operators. The result should be simplification of customs procedures in the EU for Ukrainian enterprises that have received the status of an authorized economic operator from the Ukrainian customs authorities. That is, having, for example, the privilege of primary customs clearance in Ukraine, such an enterprise will automatically use the same simplifications for customs clearance in the EU. To achieve this, Ukraine should:

$>$ Introduce changes to the legislation and subordinate normative legal acts in the field of regulating the activities of the authorized economic operators (AEO).

$>$ Negotiate with the EU on the terms of the agreement on the recognition of AEOs. Also, diplomatic channels should stimulate the EU to similar negotiations with Ukraine.

3) Accession of Ukraine to the European Customs Information System (New Customs Transit System NCTS). Accession of Ukraine to NCTS should lead to significant simplification of import-export procedures, as the customs authorities of the two parties will exchange a significant amount of information in electronic customs declarations. This will accelerate border control, since there will be no need to fill out new transit declarations on the opposite side of the border. To achieve this, Ukraine should:

$>$ Make changes to the legislation of Ukraine regarding the use of a common transit system with the EU;

$>$ Fulfill the technical requirements necessary for integrating Ukraine into the European transit system.

$>\quad$ Negotiate with the EU for the purpose of obtaining the invitation for Ukraine to accede to the NCTS Convention.

4) Introduction of paperless customs environment. Exchange of electronic documents other than customs declarations (for example, between the EU and the European Free Trade Association, electronic exchange of information through more than 200 standardized electronic documents is implemented) can significantly facilitate the free movement of goods. Distribution of electronic exchange on such documents as, for example, certificates of origin, electronic invoices, cargo documents, etc., will lead to considerable time savings during customs clearance both in the EU and in Ukraine. To achieve this, Ukraine should:

$>$ Establish technical procedures for the exchange of information on issued certificates of origin and the numbers of approved exporters;

$>$ Amend the legislation regarding the possibility of using electronic documents received from customs authorities of foreign states;

$>$ Extend control elements based on the "one-stop shop" principle based on a single EU-Ukraine information system;

$>$ Sign an agreement on informational interaction between the customs authorities of Ukraine and the EU.
5) Mutual recognition of the results of some forms of customs control (results of weighing, scanning, etc.). Customs controls are carried out on both sides of the border, for example, a customs inspection (which, as a rule, takes the most time among all measures), can be carried out both when exporting goods from Ukraine and when importing them into the EU. Establishing proper trust between the customs authorities and exchanging information on the control forms will eliminate the duplication of control forms and the loss of time associated with it. To achieve this, Ukraine should:

$>$ Coordinate the technical issues of information exchange and the extent of customs control, the results of which are recognized by an adjacent party.

$>$ Amend the legislation in terms of applying the results of the customs control carried out by the European Authorities for improving the customs control in Ukraine.

$>$ Sign an agreement on informational interaction between the customs authorities of Ukraine and the EU.

Bills aimed at confronting the above mentioned issues are already under consideration of the Parliament of Ukraine.

The need to support these bills is set out in the European Union Report on the implementation of the Association Agreement between Ukraine and the EU in 2017. This document was prepared by the European External Action Service and the European Commission for the annual meeting of the Association Council of Ukraine and the EU on December 17, 2018 in Brussels.

\subsection{Increase of the EU tariff quotas for goods from Ukraine}

With regard to expanding existing export possibilities to the EU, it is expedient to intensify the dialogue with the EU on the use of tariff quotas set for Ukraine for certain types of products and to create a commission (working group) on a regular basis with the purpose of monitoring the use of tariff quotas and introducing proposals on providing Ukraine with additional quotas for those products for which the EU demand significantly exceeds the established volume of tariff quota. In accordance with the Appendix to Annex I-A of Section IV of the Association Agreement, the EU has introduced for certain goods tariff quotas that provide for a zero import duty rate within the quota and non-zero outside the quota. The list of EU tariff quotas has 36 positions (four of them were granted additional quotas, which actually increased the number of tariff quotas to 40) and mainly contains products of agriculture and food industry.

Administration of tariff quotas is carried out by the European Commission, and the quotas themselves are divided into those given on the basis of the "first come first received" principle (provided by the Directorate General of Taxation and Customs Union in accordance with Annex II to Regulation (EU) No. 374/2014), and those given under the "import licenses" (provided by the Directorate General for Agriculture in accordance with Annex III to Regulation (EU) No. 374/2014). In both cases, the certificates EUR. 1 is a must for using quotas. 
The Ukrainian Government and the producers can not directly influence the process of distribution of tariff quotas since in accordance with the established procedure, the initiators of the use of these tariff quotas are the importing companies in the EU countries, which have the right to submit their applications for import to their governments. Subsequently, such applications are sent to the European Commission for registration. Thus, the task of the Ukrainian sellers is to find a potential buyer in the EU that could organize the filing of the relevant application, and the task for the Ukrainian Government is to create the most favorable conditions for domestic producers to find potential buyers. In this regard, in particular, it is desirable to create a database of potential buyers, which will simplify for domestic producers the process of finding business partners in the EU. Special attention should be paid to those commodity positions on which the request for domestic products by the EU member states substantially exceeds the size of the established annual quotas.

The request of EU Member States for domestic corn is more than 50 times the size of the established quota. The request for wheat under the basic quota exceeds the established size 37 times, and for an additional quota 46 times. Moreover, there is a significant surplus of the EU Member States' request for butter and dairy pastes and poultry from Ukraine. At the same time, a certain obstacle to the use of quotas for these two items is their breakdown for half a year (in the case of butter and dairy pastes) and quarter (for poultry). Thus, the request of the EU countries for an additional quarterly quota for poultry in the first quarter of 2018 amounted to more than 21 thousand tonnes at its volume of 5 thousand tonnes, and for the fourth quarter of 2018 the request was 41 tonnes at the unused balance and a new quarterly quota of 8202 tonnes. Hence, the unused volume of the quota was 8161 tonnes. At that time, there were no queries at all for three quotas (for beef and two for pork). Similar situation is observed with the annual quotas provided on the basis of the "first come - first received". Certain annual quotas were used in the first months of the year (quotas for honey and juices in 2018 were fully exhausted on January 10, 2018), indicating the need for their increase, while exports were not started in eight quotas.

It becomes clear that there is a need both for increasing the size of quotas and for improving their administration. Achievement of this goal requires mathematical calculations followed by the negotiations with the EU. Priority issue for the expansion of the export of domestic goods to the EU is the promotion of the interests of the Ukrainian exporters in the EU institutions, primarily for the purpose of defending their interests instead of accusing them of violating the trade rules established by the Association Agreement between Ukraine and the EU. An example of this practice is the accusation made by some European partners of the domestic exporter of poultry meat (the company "Myronivsky Hliboprodukt"). The essence of the allegations was that the company opened a poultry meat processing company in the EU (in Slovakia) to produce packaged products for the final consumer from semi- finished products from Ukraine. It should be noted that this example is rather demonstrative, because from a legal point of view, the domestic exporter did not violate the established rules. The mentioned company has found opportunities to increase the supply of its products, which were not foreseen at the time of concluding the Agreement, and therefore could not contradict it. This situation necessitates the study of the practice of trade by Ukrainian exporters with the EU and finding opportunities to increase exports to this market.

In our opinion, the Ukrainian Government should defend Ukrainian companies against similar accusations using all possible formats, e.g. while holding the meetings of the Association Council of Ukraine and the EU.

The implementation of all above mentioned measures will significantly simplify the administration of trade between Ukraine and the EU and will contribute to increasing exports of the Ukrainian products to the EU.

\section{Ukraine's exports during the period between 2015 and 2018 and the new role in the model of global transformation}

The first way out to increase the Ukrainian export of goods is based on the unification of markets of the EU and Ukraine, establishment of a common customs system and synchronization of its operation. Since the EU market is restricted by quotas, some researchers argue that in order to minimize risks for the agrarian sector connected with the DCFTA, leaders must improve the principles of an Euro-integration policy to accelerate works on the program of agro-industrial complex adjustment to operation under the conditions of the common European market and a common agrarian policy [23].

With regard to the exports of higher-value added products, according to the World Bank's Special Focus Note on international trade, Ukraine still has tremendous potential to boost them, but this potential has not yet been realized. The share of exports integrated with Global Value Chains (GVC) remains low at $5.7 \%$ in Ukraine, compared to $27 \%$ for Poland, $38 \%$ for Romania, 38\% for Turkey, and 59\% for Vietnam. Boosting higher-value added and GVC exports is a major opportunity for Ukraine to leverage its special access to the EU market. Ukraine has demonstrated potential on this front through the exports of automotive ignition wiring sets which grew from 21 million dollars in 2000 to 1.217 billion dollars in 2017 , one of the fastest growing export product categories in recent years [12].

The second way for realization of the Ukrainian trade potential involves exploring opportunities of the export of goods to markets of the countries, with which the EU has signed RTAs, mainly in the form of FTAs. The EU continues to conclude FTAs with countries, as well as with regional integration blocs, strengthening its trade positions not only at the regional level, but also at the global level. The EU has concluded over forty FTAs 
with countries in Europe, Asia, North America, Latin America, the Caribbean and Africa while Ukraine is characterized by half the number of trade agreements.

The talks on strategic partnership between the EU and China were launched in 2013, FTA with Japan was signed in July 2018. The EU has intensified region-toregion negotiations on future FTA with ASEAN and MERCOSUR. At the same time the talks on strategic partnership with Brazil were launched on October 27, 2017. The EU experience and coordination in trade relations with these countries will be beneficial for Ukraine.

The third way is viewed as the main one and has the nature of the fundamental novelty since it is related to the changing role of Ukraine in the global model of the transformation of the world economy.

Let's have a look at the dynamics of volume of exports of goods of Ukraine to its main consumers during the period of 2015-2018 (table 2).

The volume of total exports has increased, and the trend for the overall volume of exports is positive $y=3454 x+32638$. Exports of goods to the EU are on rise - in 2015 they amounted for 13015.2 million dollars and in 2018 have grown to 20158.5 million dollars, brining 7143.3 million dollars, which compensated for the losses of the Russian market since exports to Russia decreased by 1173.6 million dollars during the same period. So, some transformational shifts have already taken place. Trade with the CIS is slowly shrinking. There is also the tendency of export growth to Poland, Hungary, Romania, Czech Republic, Slovakia, the former members of the Council for Mutual Economic Assistance which could contribute to Ukraine's technological development. Germany, Italy, and Poland are also characterized by positive trends.

The most significant consumers of the Ukrainian products in Asia are Turkey (trend for 2015-2018 is $y=-78.82 x+2620)$, China $(y=-38.96 x+2215)$, and India $(y=249.8 x+1307)$ while the African vector of cooperation is represented by Egypt $(y=-200.3 x+2834)$.

The three problems identified in the second section are becoming even more urgent since the total volume of exports of goods in 2018 has not still reached that of 2010 , the trade deficit in goods was 6.3 billion dollars in 2017, and increased to 9.8 billion dollars in 2018 . Reforms to attract FDI should be implemented, the economy is to be integrated into GVCs. It is evident that Ukraine has large financing needs, since the IMF credits and state debts need to be paid back.

Experiencing sharp decrease in bilateral trade with Russia and still having doubts as to obtaining the status of the full member in the EU in the nearest future, Ukraine should be interested in concluding RTAs with the leading countries and regional integration organizations of the world, cooperation with which will allow Ukraine not only to increase exports of goods, but also to receive foreign direct investment ensuring innovation development path and technological leap. To sum up, Ukraine should improve trade relations with both - western and eastern partners.
Table 2. Dynamics of volume (in million dollars) and share (in \%) of goods exports of Ukraine to its main consumers.

\begin{tabular}{|c|c|c|c|c|}
\hline Countries / volume trends & 2015 & 2016 & 2017 & 2018 \\
\hline \multirow{2}{*}{$\begin{array}{l}\text { Total } \\
y=3454 x+32638\end{array}$} & 38127.1 & \begin{tabular}{|l|}
36361.7 \\
\end{tabular} & 43264.7 & 47339.9 \\
\hline & 100 & 100 & 100 & 100 \\
\hline \multirow{2}{*}{$\begin{array}{l}E U \\
y=2546 x+9684.1\end{array}$} & 13015.2 & 13496.3 & $\mathbf{1 7 5 3 3 . 4}$ & 20158.5 \\
\hline & 34.1 & 37.1 & 40.5 & 42.6 \\
\hline \multirow{2}{*}{$\begin{array}{l}\boldsymbol{C I S} \\
\boldsymbol{y}=-145.2 x+7308\end{array}$} & 7806.1 & 6031.5 & 6916.4 & 7027.0 \\
\hline & 20.5 & 16.6 & 16.0 & 14.8 \\
\hline \multirow{2}{*}{$\begin{array}{l}\text { Russia } \\
y=-317.7 x+4797\end{array}$} & 4827.7 & 3592.9 & 3936.5 & 3654.1 \\
\hline & 12.7 & 9.9 & 9.1 & 7.7 \\
\hline \multirow{2}{*}{$\begin{array}{l}\text { Poland } \\
y=436.5 x+1448\end{array}$} & 1977.3 & 2200.0 & 2724.6 & 3257.6 \\
\hline & 5.2 & 6.1 & 6.3 & 6.9 \\
\hline \multirow{2}{*}{$\begin{array}{l}\text { Italy } \\
y=248.6 x+1630\end{array}$} & 1979.8 & 1929.6 & 2469.5 & 2628.8 \\
\hline & 5.19 & 5.3 & 5.7 & 5.6 \\
\hline \multirow{2}{*}{$\begin{array}{l}\text { Turkey } \\
y=-78.82 x+2620\end{array}$} & 2771.8 & 2049.1 & 2519.1 & 2352.4 \\
\hline & 7.27 & 5.64 & 5.82 & 5.0 \\
\hline \multirow{2}{*}{$\begin{array}{l}\text { Germany } \\
y=296.9 x+936.3\end{array}$} & 1328.7 & 1423.7 & 1754.2 & 2208.4 \\
\hline & 3.5 & 3.9 & 4.05 & 4.7 \\
\hline \multirow{2}{*}{$\begin{array}{l}\text { China } \\
y=-38.96 x+2215\end{array}$} & 2399.1 & 1832.5 & 2039.3 & 2200.3 \\
\hline & 6.3 & 5.0 & 4.7 & 4.6 \\
\hline \multirow{2}{*}{$\begin{array}{l}\text { India } \\
y=249.8 x+1307\end{array}$} & 1444.1 & 1903.1 & 2205.7 & 2175.9 \\
\hline & 3.8 & 5.2 & 5.1 & 4.6 \\
\hline \multirow[b]{2}{*}{ Hungary $y=248.3 x+613.1$} & 909.7 & 1053.1 & 1326.4 & 1646.3 \\
\hline & 2.4 & 2.9 & 3.1 & 3.5 \\
\hline \multirow{2}{*}{\begin{tabular}{|l|} 
Egypt \\
$y=-200.3 x+2834$
\end{tabular}} & 2079.8 & 2266.5 & 1831.3 & 1557.1 \\
\hline & 5.5 & 6.2 & 4.2 & 3.3 \\
\hline \multirow{2}{*}{\begin{tabular}{|l} 
Belarus \\
$y=154.1 x+570.0$
\end{tabular}} & 870.7 & \begin{tabular}{|c|}
903.2 \\
\end{tabular} & 1142.9 & 1304.5 \\
\hline & 2.3 & 2.5 & 2.6 & 2.8 \\
\hline \multirow{2}{*}{$\begin{array}{l}\text { Romania } \\
y=121.3 x+462.0\end{array}$} & 569.9 & 717.0 & 841.6 & 932.7 \\
\hline & 1.5 & 2.0 & 1.94 & 2.0 \\
\hline \multirow{2}{*}{$\begin{array}{l}\text { Czech Republic } \\
y=116.5 x+382.3 \\
\end{array}$} & 541.0 & 560.8 & 715.2 & 878.1 \\
\hline & 1.4 & 1.54 & 1.65 & 1.9 \\
\hline \multirow{2}{*}{$\begin{array}{l}\text { Slovakia } \\
y=137.1 x+272.1\end{array}$} & 468.5 & 471.4 & 656.0 & 864.2 \\
\hline & 1.2 & 1.3 & 1.5 & 1.8 \\
\hline
\end{tabular}

Source: authors' calculations, based on the State Statistics Service of Ukraine database. http://www.ukrstat.gov.ua (2018) Accessed 19 Mar 2019.

\section{Conclusions}

For the first time in the scientific economic literature the development of the regional integration processes is viewed as a means of the consolidation of the world economy. Ukraine's integration processes, aimed at increasing the country's exports, play important role in consolidating West and East.

The Ukrainian Government should ensure support in the Parliament of Ukraine of bills aimed at fulfilling the terms of the EU-Association Agreement and access to the EU market, as well as address the President of Ukraine with a request for the determination of such bills as urgent. In addition, Ukraine's diplomatic missions in the EU countries should be set up to contract potential buyers of domestic products subject to tariff quotas, create an appropriate base for such buyers, as well as motivate them to appeal to their national authorities to provide tariff quotas to Ukraine.

The role of the Ukrainian Government is crucial not only for increasing the quantity of the products exports and improving their quality, but also for putting into practice the policies aimed at gaining full membership in the EU and considering new RTAs with the eastern 
countries. Ukraine should contribute to the formation of a new model of global transformation caused by the globalization processes. The novelty of the paper is the argumentation for Ukraine's integration with the EU, East Asia, and the Asia-Pacific region.

\section{References}

1. Radzievska, S.: Global economic processes and Ukraine. International Economic Policy. 1(20), 74 98 (2014)

2. Sardak, S.: The life cycle of social and economic systems. Marketing and Management of Innovations. 1, 157-169 (2016)

3. Societe Generale Business website: Country risk of Ukraine: international trade. https://importexport.societegenerale.fr/en/country/ukraine/tradecountry-risk (2018). Accessed 20 Mar 2019

4. Sidenko, V.: Ukraine's export potential: the priorities of integration. In: UCEPS National Security and Defence, pp. 48-50. https://core.ac.uk/download/pdf/11871754.pdf. Accessed 20 Mar 2019

5. Makhinova, A., Mykuliak, V.: International trade in goods and services in Ukraine: overview. https://sk.ua/wp-

content/uploads/2018/12/International-trade-ingoods-and-services-in-Ukraine-overview.pdf (2018). Accessed 20 Mar 2019

6. Kyslytska, A.: What are Ukraine's Export Priorities: the EU, CIS or Asia? June 21, 2018. Ukraine World. https://ukraineworld.org/articles/russianaggression/what-are-ukraines-export-priorities-eucis-or-asia (2018). Accessed 20 Mar 2019

7. Pradhan, H. E., Malhotra, K.: Globalization and the Least Developed Countries: Issues in Trade and Investment. Round table on issues in trade and investment: Summary of discussions. UN Ministerial Conference of the Least Developed Countries "Making Globalization Work for the Least Developed Countries". UNCTAD and UNDP (2008)

8. World Trade Organization: The Regional trade agreements information system. http://rtais.wto.org/UI/PublicAllRTAList.aspx (2019). Accessed 19 Mar 2019

9. Delegation of the European Union to Ukraine: Relations with the EU. Economic and trade relations. Full chronology of EU-Ukraine relations. https://eeas.europa.eu/delegations/ukraine/1937/ukra ine-and-eu_en (2019). Accessed 19 Mar 2019

10. Eurasian Economic Union. www.eaeunion.org (2019). Accessed 19 Mar 2019

11. European Commission: Myths about the EU Ukraine Association Agreement. Setting the facts straight.

http://trade.ec.europa.eu/doclib/docs/2014/january/tr adoc_152074.pdf (2014). Accessed 19 Mar 2019
12. The World Bank: Export of goods and services. http://data.worldbank.org (2018). Accessed 19 Mar 2019

13. The State Statistics Service of Ukraine: http://www.ukrstat.gov.ua (2018). Accessed 10 Mar 2019

14. The Program of the Cabinet of Ministers of Ukraine. Resolution of the Parliament of Ukraine № 26-VIII dated December 11, 2014 http://zakon4.rada.gov.ua/laws/show/26-19 (2014). Accessed 20 Mar 2019

15. Analytical report to the Annual Address of the President of Ukraine to the Parliament "On the internal and external state of Ukraine in 2017". National Institute for Strategic Studies (2017)

16. International Trade Administration. 2011 National Export Strategy. Powering the National Export Initiative. Trade Promotion Coordinating Committee, Washington, D.C. June 2011. https://www.trade.gov/publications/pdfs/nes2011FI NAL.pdf (2011). Accessed 20 Mar 2019

17. Progress Report on the National Export Initiative. Obama White House Archives. https://obamawhitehouse.archives.gov/sites/default/f iles/exports_progress_report.pdf. Accessed 25 Mar 2019

18. Butyter, D., Wachowska M.: Foreign trade and innovation: evidence from Ukraine. Journal of International Studies. 8(1), 173-182 (2015)

19. Aghion, P, Bergeaud A., Lequien M., Melitz M.J.: The Impact of Exports on Innovation: Theory and Evidence.

https://scholar.harvard.edu/files/aghion/files/impact of_exports.pdf (2017). Accessed 25 Mar 2019

20. Export Strategy of Ukraine: Roadmap for Strategic Development of Trade for the period 2017-2021. https://tinyurl.com/y3n3wk8o (2017). Accessed 25 Mar 2019

21. National Bank of Ukraine: Recent NBU Research Suggests and Increasing Share of European and Asian Countries and a Decreasing Share of CIS Countries in Ukraine's External Trade. 15 June 2017. https://tinyurl.com/y3tha6gw (2017). Accessed 25 Mar 2019

22. State Fiscal Service of Ukraine: http://sfs.gov.ua/ms/f1 (2018). Accessed 10 Mar 2019

23. Yatsenko, O., Nitsenko, V., Karasova, N., James, H.S.Jr., Parcell, J.L.: Realization of the potential of the Ukraine-EU free trade area in agriculture. Journal of International Studies. 10(2), 258-277 (2017). doi:10.14254/2071-8330.2017/10- 2/18 